\title{
Human study and experimental behavior of Schistosoma mansoni isolates from patients with different clinical forms of schistosomiasis
}

\author{
Maria José Conceição ${ }^{\mathrm{a}, \mathrm{c}, *}$, Henrique Leonel Lenzi ${ }^{\mathrm{b}}$, José Rodrigues Coura ${ }^{\mathrm{c}}$ \\ a Department of Preventive Medicine, Infectious and Parasitic Diseases Post-Graduation, Clementino Fraga Filho Hospital, \\ Universidade Federal do Rio de Janeiro, UFRJ, Rio de Janeiro, Brazil \\ b Laboratory of Pathology, Instituto Oswaldo Cruz, Fiocruz, Manguinhos, Rio de Janeiro, RJ, Brazil \\ ${ }^{\mathrm{c}}$ Laboratory of Parasitic Diseases, Instituto Oswaldo Cruz, Fiocruz, Manguinhos, CEP-21045-900, Rio de Janeiro, RJ, Brazil
}

\section{A R T I C L E I N F O}

\section{Article history:}

Available online 21 May 2008

\section{Keywords:}

Schistosoma mansoni

Clinical forms

Strain

Isolates

Parasite burden

Granuloma

\section{Introduction}

Several studies carried out in Brazil have speculated on the possible causes of the higher or lesser severity of schistosomiasis in the country. Studies on patients from 18 Brazilian States showed a wide variation in the severity of the disease from one region to the other (Suassuna and Coura, 1969; Coura et al., 1974, 1982). These observations were also made in a comparative study between two rural regions, subdivided in two areas in Brazilian Southeast and another two in Brazilian Northeast (Coura et al., 1983). In Minas Gerais, Brazil, Schistosoma mansoni strains isolated from patients with intestinal and hepatosplenic forms of the disease were compared in experimental infections, using mice, but differences among them were not detected (Costa et al., 1983, 1984; Costa, 1984). Anderson and Cheever (1972) also infected mice with strains of S. mansoni from Puerto Rico, Brazil (BH), Saint Lucia and Tanzania (Mwanza), but they did not detect differences in hepatic histopathology. The

* Corresponding author at: Laboratório de Doenças Parasitárias, Instituto Oswaldo Cruz, Fiocruz, Manguinhos, CEP-21045-900, Rio de Janeiro, RJ, Brazil. Tel.: +55 212286 3740; fax: +55 2122863740 .

E-mail addresses: mjconceicao@bol.com.br (M.J. Conceição), henrique.lenzi@gmail.com (H.L. Lenzi), coura@ioc.fiocruz.br (J.R. Coura). authors concluded that the results in mice probably cannot be used to predict possible differences in behavior of geographical strains of $S$. mansoni in infected person. Other histopathological study of $S$. mansoni infection in the murine model using the PC (Pará) and LILA (Maranhão) strains also did not showed significant differences between the strains (Lopes et al., 2006). No parasitological and histopathological differences between geographical strains of S. mansoni from Puerto Rico, Brazil (Belo Horizonte), Saint Lucia and Tanzania (Mwanza) were noted by Powers and Cheever (1972) in a study in mice and Rhesus monkeys using different inocula, confirming the previous results. The only strain difference observed in both mice and monkeys was a prolonged prepatent period in animals infected with the Mwanza strain. Study using DNA microsatellite as molecular marker to analyze the population structure of the laboratory LE strain and of 10 field isolates of S. mansoni showed that the LE strain has a lower total number of alleles or a lower average number of alleles/polymorphic locus than the field isolates, indicating that 41 years of laboratory maintenance exerted selective pressure on the LE strain. The $S$. mansoni populations from the field were genetically undifferentiated, suggesting a high gene flow among them (Rodrigues et al., 2002). Intraspecific genetic diversity was also detected in 14 geographical isolates of $S$. mansoni and strain diversity was substantial even among isolates from a single local site (Minchella et al., 1994). Other work, applying random amplified 
Type I - Schistosomal Infection (Group 1)

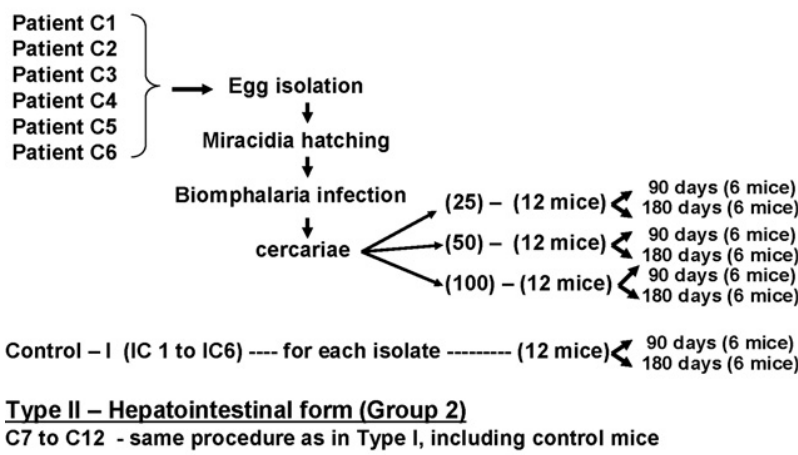

Type III - Hepatosplenic form (Group 3)

C13 to C20 - same procedure as in Type I, including control mice

Fig. 1. Scheme of the experimental design applied in the three groups of Swiss Webster mice. Each group corresponds to isolates obtained individually from each patient with different clinical forms (schistosomal infection, hepatointestinal and hepatoesplenic).

polymorphic DNA markers (RAPD) observed a limited but easily detectable polymorphism among three strains of a single species (S. mansoni) and minor differences were seen among individuals of a single strain (Barral et al., 1993).

The objective of the present study was to analyze histopathologically the experimental behavior in mice of $S$. mansoni isolates obtained from patients with different clinical forms of the disease, looking for possible correlation.

\section{Material and methods}

The study was carried out in the municipality of Capitão Andrade, Rio Doce Valley, State of Minas Gerais, an endemic area for schistosomiasis located $600 \mathrm{~km}$ from the city of Rio de Janeiro. The patients were 20 male subjects born and living in the town, ranging in age from 13 to 30 years and not submitted to previous treatment for schistosomiasis. They were divided into three groups according to the modified clinical classification (Pessoa and Barros, 1953; Barbosa, 1966): six (type I) patients with intestinal infection, six (type II) patients with the hepatointestinal form, and eight (type III) patients with the hepatosplenic form (Table 1). The experimental design is schematized in Fig. 1.

The fecal examination was done by two methods: Lutz (1919) and Kato (1960) modified by Katz et al.(1972). Biomphalaria glabrata snails were collected from the Capitão Andrade stream and allowed to adapt to the Laboratory of Parasitic Diseases (Instituto Oswaldo Cruz). The hatching and concentration of miracidia were obtained from the feces of each patient (Chaia, 1956). Twenty Biomphalariae of the third generation in the laboratory were exposed individually to 5 miracidia from each of the 20 isolates. Cercariae counts were started after 40 days. Thirty-six male albino Swiss Webster mice aged 21 days and weighing $8-11 \mathrm{~g}$ were infected with each of the 20 isolates. Twelve were infected with 25 cercariae, 12 with 50 cercariae and 12 with 100 cercariae, with a control group of 12 animals being used for each isolate. The number of cercariae was figured out by a technique developed in our laboratory consisting of counts of cercariae present in droplets, each placed with a Pasteur pipette in an individual plastic container with a $0.5 \mathrm{~cm}$ lateral orifice for the introduction of the mouse tail (Conceição et al., 1986). After cercaria counting, dechlorinated water was added and the material was homogeneously distributed. After $60 \mathrm{~min}$ of infection, the liquid was stained with lugol to estimate the number of penetrated cercariae.
After 90 and 180 days of infection, the animals were submitted to euthanasia in accordance with the animal ethical practice. Specimens of the liver, lung, intestine and spleen were collected and fixed in $10 \%$ formalin and embedded in paraffin. Five $\mu \mathrm{m}$ sections were stained with hematoxylin-eosin, Lennert's Giemsa (Lennert, 1978), Gomori's reticulin, PAS-Alcian Blue pH 1.0 and 2.5, Weigert Von Gieson and Masson's trichrome.

Periovular reaction in the liver were classified according to Li Hsü et al. (1972) modified by Lenzi et al. (1998) in: pre-granulomatous stages: weakly reactive or non-reactive and exudative stages; granulomatous stages: exudative-productive, productive and involutional granulomas. The maximum and minimum diameters were measured considering two perpendicular axes in relation to the center of the granuloma in $10 \%$ of all liver granulomas at the end of 90 and 180 days of infection. A LutzWetzlar ocular micrometer fitted to a Zeiss light microscope and calibrated according to Ellis (1974) was used. The mean volume in $\mathrm{mm}^{3}$ was estimated considering the granuloma to be a spherical figure (Cheever, 1965), applying the formula $V=4 / 3 \pi r^{3}$ (Lemos et al., 1978).

\subsection{Human liver biopsy}

Needle aspirative biopsies of the liver were obtained, after informed consent, from five patients in the groups II and from three patients in the group III using a Menghini's needle. Liver fragments were also taken during surgery from two type-III patients (samples $\mathrm{C}_{14}$ and $\mathrm{C}_{17}$ ). Sections were fixed, in $10 \%$ formalin, processed and stained as was done in the experimental study. Human granulomas were classified on 4 phases: necrotic-exudative, exudative, productive, and fibrotic (Raso and Neves, 1965).

\section{Results}

\subsection{Human patients}

Table 1 summarizes the main clinical characteristics of patients infected with S. mansoni according to clinical stage, age, color, occupation and size of liver and spleen.

The main alterations observed in the histopathological analysis of the liver biopsies from five type-II patients were: productive granuloma with eosinophilic exudation in four cases and exudative necrotic in one. Hoeppli phenomenon was detected in two cases. The biopsies showed also hypertrophy of Kupffer cells with schistosomal pigment and increased perisinusoidal reticulin framework. Only in one case, viable and dead eggs were seen. In five biopsies from type-III patients, the main results were the following: the granulomas varied from exudative, productive, advanced productive and involutional types. The involutional granulomas consisted exclusively of giant cells, engulfing dead eggs. Portal fibrosis presented lymphoplasmacytic and macrophage infiltrates and emission of fibrous septa, delimiting pseudonodules. There was increase of the perisinusoidal reticulin.

\subsection{Experimental study}

\subsubsection{Histopathological changes in the liver}

In all the groups, in the liver of 90 days of infection, the reactions ranged from incipient accumulation of inflammatory cells (monocyte/macrophages, eosinophils and some lymphocytes) to formation of different stage granulomas, mainly of exudativeproductive type (Table 2 ). Most of the miracidia were viable.

The granulomas in all the groups exhibited more or less the same cell types. Focal areas of eosinophilic metaplasia were frequent in the external layer of the granulomas. In some exudative-productive 
Table 1

Distribution of patients infected by Schistosoma mansoni according to clinical stage, age, color, occupation and size of liver and spleen

\begin{tabular}{|c|c|c|c|c|c|c|c|}
\hline \multirow[t]{2}{*}{ Patient } & \multirow[t]{2}{*}{ Name } & \multirow[t]{2}{*}{ Age } & \multirow[t]{2}{*}{ Color } & \multirow[t]{2}{*}{ Occupation } & \multirow{2}{*}{$\begin{array}{l}\text { Size of liver }(\mathrm{cm}) \\
\text { XA }\end{array}$} & \multicolumn{2}{|c|}{ and spleen $(\mathrm{cm})$} \\
\hline & & & & & & RCE & LCE \\
\hline \multicolumn{8}{|c|}{ Type I: infection } \\
\hline C1 & AFM & 13 & W & Student & - & - & - \\
\hline $\mathrm{C} 2$ & VFM & 15 & W & Farmer & - & - & - \\
\hline $\mathrm{C} 3$ & EFS & 13 & W & Student & - & - & - \\
\hline $\mathrm{C} 4$ & AVS & 28 & M & Farmer & - & - & - \\
\hline $\mathrm{C} 5$ & CFM & 14 & W & Student & - & - & - \\
\hline C6 & LCC & 13 & W & Student & - & - & - \\
\hline \multicolumn{8}{|c|}{ Type II: hepatointestinal } \\
\hline$C 7^{\mathrm{a}}$ & HPF & 21 & M & Farmer & 12 & 4 & - \\
\hline$C 8^{\mathrm{a}}$ & ACC & 13 & W & Student & 10 & 4 & - \\
\hline $\mathrm{C} 9^{\mathrm{a}}$ & $A C$ & 21 & W & Farmer & 10 & 3 & - \\
\hline $\mathrm{C} 10$ & HV & 17 & W & Farmer & 10 & 5 & - \\
\hline $\mathrm{C} 11^{\mathrm{a}}$ & VFB & 13 & W & Student & 8 & 3 & - \\
\hline $\mathrm{C} 12^{\mathrm{a}}$ & MFM & 13 & W & Student & 10 & 4 & - \\
\hline \multicolumn{8}{|c|}{ Type III: hepatosplenic } \\
\hline C13 & JPO & 19 & M & Farmer & 5 & 0 & b \\
\hline $\mathrm{C} 14^{\mathrm{a}}$ & PGL & 13 & M & Student & 14 & 7 & 13 \\
\hline $\mathrm{C} 15^{\mathrm{a}}$ & IBO & 22 & M & Farmer & 10 & 0 & 8 \\
\hline C16 & DO & 30 & $\mathrm{M}$ & Farmer & 9 & 3 & 6 \\
\hline $\mathrm{C} 17^{\mathrm{a}}$ & EHC & 19 & W & Cowboy & 9 & 5 & 8 \\
\hline C18 & DGL & 23 & $\mathrm{M}$ & Farmer & 5 & 0 & b \\
\hline $\mathrm{C} 19^{\mathrm{a}}$ & FMS & 22 & W & Cowboy & 10 & 4 & 1.5 \\
\hline $\mathrm{C} 20^{\mathrm{a}}$ & JLO & 18 & W & Farmer & 8 & 5 & 1.5 \\
\hline
\end{tabular}

XA: xiphoid appendix; RCE: right costal edge; LCE: left costal edge; W: white; M: mullato.

a Cases in whom hepatic biopsies were performed.

b Patients submitted to splenectomy.

granulomas there were also central accumulations of intact or degenerated neutrophils around or inside dead miracidia. Mast cells, when present, were irregularly distributed (average of six per exudative-productive granuloma), were metachromatic in Giemsa and alcian blue positive at $\mathrm{pH} 1$ and especially at $\mathrm{pH} 2.5$. Plasma cells and small or large (lymphoblastoid) lymphocytes were located almost always at the periphery of the granulomas. Schistosomal pigment was observed especially inside macrophages in the periphery of the granulomas and in Kupffer cells. Some dead or necrotic adult worms were also surrounded by a granulomatous reaction.

After 180 days of infection, the granulomas of samples from groups I, II and III acquire the same stages already described in animals with 90 days of infection, presenting also productive granulomas (Table 2). These predominated in $78 \%$ of the samples, whereas in the rest the exudative-productive granulomas constituted the predominant type. Although the cellular composition was similar to that observed at 90 days, the mean diameter and volume were smaller, indicating modulation (Table 3 ). The transition of productive granulomas to the involutional stage was infrequent.

Table 2

Types of hepatic granulomas of the three groups in Swiss Webster mice infected with 25,50 and $100 \mathrm{~S}$. mansoni cercariae, after 90 and 180 days of infection

\begin{tabular}{|c|c|c|c|c|c|c|}
\hline \multirow[t]{3}{*}{ Granulomas types } & \multicolumn{6}{|c|}{ Time of infection (days) } \\
\hline & \multicolumn{3}{|l|}{90} & \multicolumn{3}{|l|}{180} \\
\hline & 25 & 50 & 100 & 25 & 50 & 100 \\
\hline Weakly reactive & + & + & + & + & + & + \\
\hline Exudative & ++ & ++ & ++ & + & + & + \\
\hline Exudative-necrotic & $-\backslash+$ & $-\rangle^{+}$ & $-\rangle^{+}$ & - & - & - \\
\hline Exudative-productive & +++ & +++ & +++ & ++ & ++ & ++ \\
\hline Productive & - & - & - & +++ & +++ & +++ \\
\hline Involutive & - & - & - & - & $-1+$ & $-\backslash+$ \\
\hline
\end{tabular}

-: non-existent; $-\backslash+$ to +++: increasing levels of predominance.
Portal fibrosis was uncommon in all groups and eosinophils and plasma cells, were the predominant cells in portal spaces, in addition to some small and/or activated lymphocytes. Ductal cells presented areas of hypertrophy and hyperplasia with oxyphilic alteration, and exhibited apical secretion (alcian blue at pH 1.0 and pH 2.5 positive).

No vascular alterations were observed at the arteriole level and the venules were sometimes dilated due to the presence of adult worms in the lumen. Focal dilatation of smaller portal vessels was rarely observed and these vessels never had an angiomatoid aspect similar to that observed in the portal spaces of human livers with advanced schistosomiasis. Thrombotic phenomena inside the venules were rarely seen.

Microgoticular or focal periportal steatosis was occasionally detected in the hepatic parenchyma, together with frequent zones of focal necrosis surrounded by a neutrophilic exudate, and absence of regeneration. Kupffer cells were hypertrophied and contained schistosomal pigment. The reticulin framework showed frequent and variable alterations characterized by periportal, subcapsular and central collapse, presence of porto-portal septa, and focal perisinusoidal thickening. Adult worms inside the intrahepatic venules predominated in the samples from animals inoculated with 50 and 100 cercariae.

\subsubsection{Histopathological changes in the intestine}

In the small intestine of animals from all groups studied at 90 and 180 days, the granulomas usually consisted of central zone of macrophages, surrounded by concentric layers of fibroblastic-like cells (fibroblastoids) intermingled with reticulin fibers. Neutrophils and eosinophils were more clustered in the center or scattered throughout the area of the granulomas. Lymphocytes were arranged in a more diffuse manner than in the hepatic granulomas and plasma cells were rare. Schistosomal pigment and perigranulomatous eosinophil metaplasia were never detected. The granulomas were mainly located in the submucosal and subserosal layers, and less frequently in the mucosal and muscular layers. 
Table 3

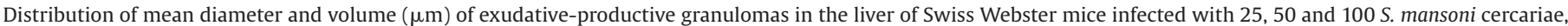
after 90 and 180 days of infection

\begin{tabular}{|c|c|c|c|c|c|c|}
\hline \multirow[t]{3}{*}{ Number of cercariae } & \multicolumn{6}{|c|}{ Time of infection (days): granuloma in liver } \\
\hline & \multicolumn{3}{|l|}{90} & \multicolumn{3}{|l|}{180} \\
\hline & Diameter $(\mu \mathrm{m})$ & Standard deviation & Volume $\left(\mathrm{mm}^{3}\right)$ & Diameter $(\mu \mathrm{m})$ & Standard deviation & Volume $\left(\mathrm{mm}^{3}\right)$ \\
\hline \multicolumn{7}{|l|}{ Group I } \\
\hline 25 & 203.2 & $(11.5)$ & 0.0044 & 115.5 & $(7.2)$ & 0.00081 \\
\hline 50 & 210.2 & $(4.2)$ & 0.0048 & 134.0 & $(4.4)$ & 0.0012 \\
\hline 100 & 202.0 & $(4.2)$ & 0.0043 & 166.5 & $(11.4)$ & 0.0023 \\
\hline \multicolumn{7}{|l|}{ Group II } \\
\hline 25 & 197.0 & $(14.0)$ & 0.0030 & 135.5 & $(17.6)$ & 0.0019 \\
\hline 50 & 201.5 & $(7.8)$ & 0.0043 & 144.0 & (3.3) & 0.0015 \\
\hline 100 & 206.3 & (11.5) & 0.0060 & 140.5 & $(4.4)$ & 0.0019 \\
\hline \multicolumn{7}{|l|}{ Group III } \\
\hline 25 & 212.2 & (13.4) & 0.0065 & 160.0 & $(2.1)$ & 0.0021 \\
\hline 50 & 192.0 & (3.8) & 0.0037 & 154.0 & $(2.7)$ & 0.0019 \\
\hline 100 & 213.5 & $(2.9)$ & 0.0051 & 176.0 & $(6.5)$ & 0.0028 \\
\hline
\end{tabular}

$F=22.5>0.05$ (NS) $(F$ : variance factor).

In some cases, mast cells occurred in larger numbers in the muscular and subserosal layers and were more frequent in the paracentral and peripheral regions of the granulomas. These mast cells presented the same staining characteristics as the hepatic mast cells.

Eggs with absent or weak periovular reaction were located in the mucosa (intravascular localization), in the submucosa and subserosa (extravascular localization). In the intestinal mucosa not involved by the presence of granulomas, the mononuclear cellularity of the chorion was within normal limits and only an increase in the number of eosinophils was noted. In the large bowel, the granulomas were similar to those observed in the small intestine and were located in the mucosal, submucosal and subserosal layers. Eggs with a weak or absent reaction were detected in the mucosa (intravascular), submucosa and subserosa (extravascular). The mucosa not involved by the granulomas was within normal limits. Light fibrosis was observed in the submucosa and subserosa.

\subsubsection{Histopathologic changes in lung}

In the lungs at 90 and 180 days of infection, the composition of the granulomas in all the groups showed a strong predominance of monocytes/macrophages, which rarely matured into epithelioid cells or formed giant cells. Eosinophils predominated over neutrophils and both were diffusely located in the granulomas. No mast cells or plasma cells were seen. Cells with the aspect of fibroblasts were scarce. The granulomas sometimes were confluent, with infrequent central necrosis. The granulomas were located in paravascular, peribronchial, alveolar and intravascular positions.

The presence of intravascular adult worms was more frequent in animals infected with 50 and 100 cercariae.

Among the nonspecific changes detected in some cases, particularly prominent were vascular congestion, intra-alveolar hemorrhages, increased number of intra-alveolar macrophages and of the paravascular and parabronchial lymphoid component. In two animals of the $C_{16}$ sample from group-III, thickening of the intima with unfolding of the internal elastica was observed in arterial vessels.

Comparative analysis of the cell composition of the granulomas in the liver, intestine and lungs of the animals sacrificed at 90 and 180 days showed that macrophages, epithelioid cells, eosinophils, neutrophils, plasma cells and mast cells predominated in hepatic granulomas. Presence of schistosomal pigment and hematopoietic metaplasia were only identified in hepatic granulomas. Other differential alterations between the granulomas of these three organs were described above in the text.

\subsubsection{Histopathologic changes in the spleen}

In the spleen from all the groups, the largest number of granulomas was observed after inoculation of 50 and 100 cercariae. The periovular reaction was heterogeneous, ranging from isolated eggs without reaction to eggs surrounded by granulomas in various phases, mainly productive ones, in transition to fibrotic stage. Mast cells were present in the granulomas.

\subsubsection{Quantitative analysis}

The mean number of granulomas in the liver, spleen, lungs, and small and large intestine was proportional to the inocula (data not shown). Table 3 shows the mean diameters of the exudativeproductive hepatic granulomas and their respective volumes at 90 and 180 days of infection. Analysis of variance of the differences in the mean diameters of the hepatic granulomas in the group samples compared to the differences that occurred within groups (residues) did not show a significant difference between them on the basis of the calculation of the variance ratio $(F)$. The $F$ value was 22.5 , i.e., higher than the 0.05 level of significance. A similar result was obtained when the inoculum was considered as one source of variation.

The ratio of the variance of the differences between the means obtained for another factor studied, i.e. time of infection, compared to the differences of the means observed within groups (residues) led to a significant difference with respect to time as a factor of variation $(F=2.9<0.05)$. The comparison between means showed that the $t$ value was significant for all groups $\left(x_{2}-x_{1}\right.$ : $t=1.8<0.05)$.

\section{Discussion}

Here we showed that even an exhaustive histopathological analysis in infected mice with $S$. mansoni isolates from patients with different clinical forms, proceeding from the same geographical area, did not allow to detect significative differences in the tissue reaction in the liver, intestine, spleen and lung among the animals. These data indicate three possibilities: (1) mouse model in not adequate to predict possible differences in the $S$. mansoni isolates obtained from patients; (2) field isolates are probably genetic polymorphic and undifferentiated; (3) schistosomiasis in human does not depend on parasite intrinsic factors, but on multivariable factors, such as intensity and duration of infection, time of infection, age and gender (Mohamed-Ali et al., 1999). Dessein's Laboratory, in collaboration with researchers of the University of Gezira demonstrated that the genetic make-up of the host plays an important role 
in susceptibility to periportal fibrosis, and a major susceptibility gene has been mapped on chromosome 6 (6q22-q23) near the gene encoding $\alpha$-chain of the IFN- $\gamma$ receptor (Dessein et al., 1999). Otherwise, low IFH- $\gamma$ producers have been shown to have an increased risk of severe periportal fibrosis, due to the antifibrogenic and profibrolytic effects of IFN- $\gamma$ (Chevillard et al., 2003). In our study in mice, the histopathological alterations were only proportional to the inoculum used and the duration of the infection. Thiongo et al. (1997), using a mouse model to test isolates from two different areas of Machakos District, Kenya, concluded that the results provided some support to the hypothesis that parasite-related differences in pathobiological characteristics may at least contribute to the marked difference observed in S. mansoni-induced morbidity between the Kangundo and Kibwezi areas.

LoVerde et al. (1985) showed that, depending on the host, there is a selection against particular alleles of S. mansoni. In fact, the vertebrate host-induced selection resulted in a decrease in parasite variability due to loss of alleles as field isolates of $S$. mansoni were passaged in murine host. The use of non-human primate (baboons) hosts, on the other hand, maintained a higher level of parasite variability.

The patients were classified according to traditional clinical criteria and ultrasound examination only in those inhabitants with hepato and hepatosplenomegaly that were assisted in the Hospital Universitário. However, it was not applied in all the population due to logistic problems in the field. This was a limitation of the study, although this problem was not solved yet considering also the limitations of the sonographic procedure. More recently, the finding of periportal fibrosis in sonographic examination has been questioned when magnetic resonance imaging (MRI) to confirm the diagnosis of liver periportal fibrosis was used (Silva et al., 2006). A significant number of patients diagnosed as having periportal fibrosis by ultrasound was shown to have, by MRI, fat infiltration of the periportal tracts. Marinho et al. (2006) and Joshi et al. (2004) found low precision of physical examination in identifying spleno and hepatomegaly. However, these limitations did not invalidate this study, considering the large clinical experience of the clinician (JRC) and the unquestionable heterogeneity among the patients versus the homogeneity in the mice responses. Even the liver biopsies, although in low number, did not develop clear histopathological differences between the livers of hepatointestinal and hepatosplenic patients.

Other parameters, such as egg count in the small and large intestines, adult worm recovery and natural mortality were also verified in mice infected with the same isolates used in this paper and the results were the following: the average number of worms obtained by perfusion from groups I, II and III were $21.9 \%, 22 \%$ and $17.8 \%$, respectively. The average natural mortality rates of mice submitted to infection with 25,50 and 100 cercariae were, respectively, $12.4 \%, 23.2 \%$ and $40.2 \%$ for group I, $4.7 \%, 19.5 \%$ and $22.2 \%$ for group II and $11.4 \%, 29.5 \%$ and $41.6 \%$ for group III, being therefore proportional to the inocula and the time of infection independently from the clinical form of the isolates. The number of S. mansoni eggs was also always proportional to the inoculum and the highest number of eggs was found in the median and proximal portion of the intestines in the three groups (Conceição and Coura, 1986). The infection of Biomphalaria glabrata with the same isolates showed a great variation of the number of cercariae produced by some of those isolates in the same system, without relation with the clinical forms of the disease (Conceição et al., 1986).

The histopathological analysis in mice was extensive and intensive, looking in some of the main places affected by the infection (liver, intestines, lung and spleen), using several special histological stains in animals infected with isolates obtained from three clinical forms, tested with three inocula (25, 50 and 100 cercariae), following two different times of infection (90 and 180 days). These times correspond to transition from acute to chronic stage (90 days) and chronic stage (180 days). Even so, no differences were detected among the groups and the results described were in accordance with reports based in mice infection with isolates traditionally utilized in research laboratories (Lenzi et al., 1998; Cheever et al., 2002).

Although all the trials, even this work, to demonstrate possible intraspecific variability in S. mansoni using parasitological and histopathological evaluations have failed, other authors have succeed in detecting interspecific differences using traditional methodologies. Erickson et al. (1974) studied differences in the granulomatous response of hamsters infected with S. mansoni, $S$. haematobium and S. japonicum by measuring granulomas in the liver. The mean volume of granulomas in S. mansoni infected hamsters was greater than in those with other species at all time intervals studied. The decrease in granuloma size with time occurred more gradually in $S$. mansoni infections. This study provides further evidence of an intrinsic qualitative difference in the eggs of the three species, i.e., the species of eggs present in tissues apparently has greater influence on the host response than the quantity of eggs present. Edungbola et al. (1982) compared hepatic granuloma formation around of exogenous eggs of S. mansoni and S. japonicum surgically injected, controlling the quantity of eggs, the sequence of their arrival in the liver, the timing of observation, and the strain of experimental animals. They concluded that the most severe and fatal effects produced by eggs of S. japonicum are largely due to differences in the cytotoxic and antigenic peculiarities of this species.

In conclusion this study indicated that there was no correlation between the clinical forms of schistosomiasis in humans and the behavior of the respective isolates of S. mansoni in mice, emphasizing the fact that the histopathological alterations observed in mice were only proportional to the inoculum and the time of infection, demonstrating the importance of the quantitative variables in the determination of the disease. In the future, this type of study should be improved by imaging diagnosis, genomic (e.g. microarray) and proteomic procedures, followed by Systems Biology, looking for a systems-wide perspective (Nicholson et al., 2004; Wolkenhauer and Mesarovic, 2005; Boogerd et al., 2007).

\section{Acknowledgments}

In memoriam to Mozar José Coelho. We thank to Jane Arnt Lenzi; M.D., Ph.D. for the scientific review of the manuscript, and Acyr Correa, Elcyr Correa, Maria de Lourdes Gomes de Carvalho, Luzia de Fátima Gonçalves Caputo, Filomena de Fátima Cruz, Patrícia Ingrid Medeiros Branco Luiz, Éricka Arregue de Lemos and José Reinaldo Conceição for the technical assistance.

Financial support: This work was supported by Conselho Nacional de Desenvolvimento Científico e Tecnológico - CNPq, Fiocruz and Federal University of Rio de Janeiro-UFRJ.

\section{References}

Anderson, L.A., Cheever, A.W., 1972. Comparison of geographical strains of Schistosoma mansoni in the mouse. Bull. WHO 46, 233-242.

Barbosa, F.A.S., 1966. Morbidade da Esquistossomose. Rev. Bras. Malariol. Doenças Trop. Número especial, 3-159.

Barral, V., This, P., Imbert-Establet, D., Combes, C., Delseny, M., 1993. Genetic variability and evolution of the Schistosoma genome analysed by using random amplified polymorphic DNA markers. Mol. Biochem. Parasitol. 59, 211-221.

Boogerd, F.C., Bruggeman, F.J., Hofmeyer, J.-H.S., Westerhoff, H.V., 2007. Systems. Biology-Philosophical Foundations. Elsevier, Amsterdam, 342 pp.

Chaia, G., 1956. Técnica para concentração de miracídios. Rev. Bras. Malariol. Doenças Trop. 8, 355-357.

Cheever, A.W., 1965. A comparative study of Schistosoma mansoni infections in mice gerbils, multimammate rats and hamsters. I. The relations of portal hypertension to size of hepatic granuloma. Am. J. Trop. Med. Hyg. 14, 211-226. 
Cheever, A.W., Lenzi, J.A., Lenzi, H.L., Andrade, Z.A., 2002. Experimental models of Schistosoma mansoni infection. Mem. Inst. Oswaldo Cruz 97, 917-940.

Chevillard, C., Moukoko, C.E., Elwali, N.E.M.A., Bream, J.H., Kouriba, B., Argiro, L. Rahoud, S., Mergani, A., Henri, S., Gaudart, J., Mohamed-Ali, Q., Young, H.A., Dessein, A.J., 2003. IFN- $\gamma$ polymorphisms (IFN- $\gamma+2109$ and IFN- $\gamma+3810$ ) are associated with severe hepatic fibrosis in human hepatic schistosomiasis (Schistosoma mansoni). J. Immunol. 171, 5596-5601.

Conceição, M.J., Coura, J.R., 1986. Comportamento Experimental de Amostras de Schistosoma mansoni em relação às formas clínicas de Esquistossomose. I. Estudo em camundongos. Mem. Inst. Oswaldo Cruz 81, 61-66.

Conceição, M.J., Coura, J.R., Cheever, A.W., 1986. Variabilidade de cepas de Schistosoma mansoni na produção de cercárias. Mem. Inst. Oswaldo Cruz 81, 473-474.

Costa, M.F.F.L., 1984. Estudo Clínico-epidemiológico da Esquistossomose manson em Comercinho, Minas Gerais (1974-1981). Doctoral Thesis. Faculdade de Medicina da Universidade Federal de Minas Gerais, 207 pp.

Costa, M.F.F.L., Rocha, R.S., Katz, N., 1984. Comparative study of Schistosoma mansoni isolated from patients with hepatosplenic intestinal clinical forms of schistosomiasis. Am. J. Trop. Med. Hyg. 33, 918-923.

Coura, J.R., Conceição, M.J., Menezes, A.P., Santos, M.L., Mendonça, M.Z.G., 1983. Morbidade da Esquistossomose mansoni no Brasil. II. Estudo em quatro áreas de campo nos Estados de Minas Gerais, Sergipe e Paraíba. Mem. Inst. Oswaldo Cruz $78,1-11$.

Coura, J.R., Queiroz, G.C., Florêncio, C.G., Argento, C.A., Coutinho, S.G., Figueiredo, N. Wanke, B., Camillo-Coura, L., 1982. Morbidade da esquistossomose mansoni no Brasil. I. Estudo de 4.652 casos observados no Rio de Janeiro de 1960 a 1979. Mem. Inst. Oswaldo Cruz 77, 69-88.

Coura, J.R., Wanke, B., Figueiredo, N., Argento, C.A., 1974. Evolutive pattern of schistosomiasis and life-span of Schistosoma mansoni in patients living in non-endemic area in Brazil. Rev. Soc. Bras. Med. Trop. 8, 193-198.

Dessein, A.J., Hillaire, D., Elwali, N.E.M.A., Marquet, S., Mmohamed-Ali, Q., Mirghani, A., Henri, S., Abdelhameed, A.A., Saeed, O.K., Magzoub, M.M.A., Abel, L., 1999. Severe hepatic fibrosis in Schistosoma mansoni infection is controlled by a majo locus that is closely linked to the interferon- $\gamma$ receptor gene. Am. J. Hum. Genet 65, 709-721.

Edungbola, L.D., Cha, Y.N., Bueding, E., Schiller, E.L., 1982. Granuloma formation around exogenous eggs of Schistosoma mansoni and Schistosoma japonicum in mice. Afr. J. Med. Med. Sci. 11, 75-79.

Ellis, L.D., 1974. Calibration of the ocular micrometer. In: Manual of Quality Contro Procedures for Microbiological Laboratories. Department of Health, Education and Welfare, Atlanta, Georgia, pp. 73-74.

Erickson, D.G., Jones, C.E., Tang, D.B., 1974. Schistosomiasis mansoni, haematobia and japonica in hamsters: liver granuloma measurements. Exp. Parasitol. 35 425-433.

Joshi, R., Singh, A., Jajoo, N., Pai, M., Kalantri, S.P., 2004. Accuracy and reliability of palpation and percussion for detecting hepatomegaly: a rural hospital-based study. Indian Am. J. Gastroenterol. 23, 171-174.

Kato, K., 1960. A correct application of the thick-smear technique with cellophane paper cover. A pamphlet 9p. In: Komiya, Y., Kobayashi, A. (Eds.), Evaluation of Kato Thick Smear Technique with a Cellophane Cover for Helminth Eggs in Feces. Jpn. J. Med. 19, 59-64.

Katz, N., Chaves, A., Pellegrino, J., 1972. A simple device for quantitative stool thicksmear technique in Schistosomiasis mansoni. Rev. Inst. Med. Trop. São Paulo 14 397-400.

Lemos, A.A., Higuchi, F., Fridman, S., 1978. Geometria. In: Matemática. Série Sinopse. São Paulo. Ed. Moderna, pp. 169-202.
Lennert, K., 1978. Malignant Lymphomas Other Than Hodgkin's Disease. SpringerVerlag, Berlin, 833 pp.

Lenzi, H.L., Kimmel, E., Schechtman, H., Pelajo-Machado, M., Romanha, W.S., Pacheco, R.G., Mariano, M., Lenzi, J.A., 1998. Histoarchitecture of schistosomal granuloma development and involution: morphogenetic and biomechanical approaches. Mem. Inst. Oswaldo Cruz 93 (Suppl.), 141-151.

Li Hsü, S.Y., Hsü, H.F., Davis, J.R., Lust, G.L., 1972. Comparative studies on the lesions caused by eggs of Schistosoma japonicum and Schistosoma mansoni in livers of albino mice and rhesus monkeys. Ann. Trop. Med. Parasitol. 66, 89-97.

Lopes, I.C., Santos, V.R.C., Souza, V.L.R.B., Rodrigues, I.R.C., 2006. Histopathological study of Schistosoma mansoni infection in the murine model using the PC (Pará) and LILA (Maranhão) strains. Mem. Inst. Oswaldo Cruz 101 (Suppl. 1), 273-277.

LoVerde, P.T., DeWald, J., Minchella, D.J., Bosshardt, S.C., Damian, R.T., 1985. Evidence for host-induced selection in Schistosoma mansoni. J. Parasitol. 71, 297301.

Lutz, A., 1919. O Schistosomum mansoni e a schistosomatose segundo observações feitas no Brasil. Mem. Inst. Oswaldo Cruz 11, 121-155.

Marinho, C.C., Voieta, I., Azeredo, L.M., Nishi, M.P., Batista, T.S., Pereira, A.C.F., Serufo, J.C., Queiroz, L.C., Ruiz-Guevara, R., Antunes, C.M., Prata, A., Lambertucci, J.R., 2006. Clinical versus ultrasound examination in the evaluation of hepatosplenic schistosomiasis mansoni in endemic areas. Mem. Inst. Oswaldo Cruz 101 (Suppl. I), 317-321.

Minchella, D.J., Lewis, F.A., Sollenberger, K.M., Williams, J.A., 1994. Genetic diversity of Schistosoma mansoni: quantifying strain heterogeneity using a polymorphic DNA element. Mol. Biochem. Parasitol. 68, 307-313.

Mohamed-Ali, Q., Elwali, N.-E.M.A., Abdelhaamed, A.A., Mergani, A., Rahoud, S., Elagib, K.E., Saeed, O.K., Abel, L., Magzoub, M.M.A., Dessein, A.J., 1999. Susceptibility to periportal (Symmers) fibrosis in human Schistosoma mansoni infections: evidence that intensity and duration of infection, gender, and inherited factors are critical in disease progression. J. Infect. Dis. 180, 1298-1306.

Nicholson, J.K., Holmes, E., Lindon, J.C., Wilson, I.D., 2004. The challenges of modeling mammalian biocomplexity. Nat. Biotechnol. 22, 1268-1274.

Pessoa, S.B., Barros, P.R., 1953. Notas sobre a epidemiologia da esquistossomose mansônica no Estado de Sergipe. Rev. Med. Cir. São Paulo 13, 147-154.

Powers, G.P., Cheever, A.W., 1972. Comparison of geographical strains of Schistosma mansoni in the Rhesus monkeys. Bull. WHO 46, 295-300.

Raso, P., Neves, J., 1965. Contribuição ao conhecimento do quadro anatômico do fígado na forma toxêmica da esquistossomose mansoni através de punções biópsias. An. Fac. Med. Univ. Fed. Minas Gerais 22, 147-165.

Rodrigues, N.B., Coura-Filho, P., Souza, C.P., Passos, J.L.K., Dias-Neto, E., Romanha, A.J., 2002. Populational structure of Schistosoma mansoni assessed by DNA microsatellites. Int. J. Parasitol. 32, 843-851.

Silva, L.C.S., Pereira, A.C.F., Queiroz, L., Andrade, L.M., Antunes, C.M.F., Lambertucci, J.R., 2006. Disagreement between ultrasound and magnetic resonance imaging in the identification of schistosomal periportal fibrosis. Mem. Inst. Oswaldo Cruz 101 (Suppl. I), 279-282.

Suassuna, A., Coura, J.R., 1969. Esquistossomose mansoni no Estado da Guanabaraaspectos epidemiológicos das migrações internas. Rev. Soc. Bras. Med. Trop. 3, 59-71.

Thiongo, F.W., Madsen, H., Ouma, J.H., Andreassen, J., Christensen, N.O., 1997. Host-parasite relationship in infections with two Kenyan isolates of Schistosoma mansoni in NMRI mice. J. Parasitol. 83, 330-332.

Wolkenhauer, O., Mesarovic, M., 2005. Feedback dynamics and cell function: why systems biology is called Systems Biology. Mol. Biosyst. 1, 14-16. 